\title{
Kant, Hegel, and Habermas: Does Hegel's Critique of Kant Apply to Discourse Ethics?
}

\section{Matthew Miller}

The University of South Carolina

The question that I have offered as the subtitle of this essay is one that German philosopher Jurgen Habermas felt personally obliged to answer in an essay entitled Morality and Ethical Life: Does Hegel's Critique of Kant Apply to Discourse Ethics.' There, Habermas acknowledges the great degree of similarity between his discourse ethics and Kant's moral philosophy. ${ }^{2}$ He also accepts the cogency of Hegel's criticisms of Kant. He rejects, however, the idea that Hegel's critique applies to discourse ethics. After a brief exposition of discourse ethics, Habermas identifies what he understands to be the key points of similarity and difference between his theory and Kant's. Then he explains the degree to which four of Hegel's most trenchant criticisms of Kant apply to discourse ethics. ${ }^{3}$ He claims, "Hegel's objections apply less to the reformulations of Kantian ethics itself than to a number of resulting problems that discourse ethics cannot be expected to resolve in a single stroke." Habermas argues that the problems with discourse ethics do not stem from its justification but rather its application. He professes a firm belief in the ability of moral argumentation to produce a political situation in which the competing aims of individual rights and solidarity are realized.

The general aim of this essay is to respond to Habermas and to reexamine the Hegelian idea that the issues of justification and application cannot really be separated. In what follows, I will review the similarities that Habermas acknowledges between discourse ethics and Kant's moral philosophy. Second, I will argue that the differences that Habermas sees between himself and Kant are inessential. Habermas' rethinking of the universalist project does not move it beyond Kant in any fundamental way. Finally, I will argue that discourse ethics, despite Habermas' protests, is just as susceptible to Hegelian critique as Kant's moral philosophy. 
Habermas uses the adjectives deontological, cognitivist, formalist and universalist to describe the most general features of discourse ethics. ${ }^{5}$ Each of these terms can be applied with equal veracity to the Kantian moral world-view. ${ }^{6}$ Both Kantianism and discourse ethics are deontological insofar as each of them requires the moral agent to appeal to a general rule in order to determine the legitimacy of any particular rule. For Kant, if I wish to know whether or not I ought to take the maxim "do not lie" as the basis for some action of mine (e.g. explaining to my wife where I have been or completing my taxes), I must authenticate it by determining whether or not it is consistent with my recognition of the freedom of all other rational beings. I must be able to will that any maxim upon which I base my actions ought to become universal law. ${ }^{7}$ In Habermas' discourse ethics, normative validity claims (i.e. moral maxims) are legitimized by evaluating them according to principle U. Principle U states, "All affected can accept the consequences and the side effects its (i.e. the moral proposition in question) general observance can be anticipated to have for the satisfaction of everyone's interests." ${ }^{8}$ Habermas asserts that U bridges the gaps between the interests of the participants in a moral discourse. The various normative validity claims introduced by participants in a moral discourse can be redeemed only through this general rule.

Another feature that discourse ethics and Kant's practical philosophy share is an emphasis on the cognitive dimension of morality. A moral theory is cognitivist if it sets forth an explicit principle of justification (e.g. the C.I., or principle U). It must provide an answer to the question of why one moral norm is better than some other norm which conflicts with it. Habermas contends that justification of moral norms is analogous to the justification process that goes on in the natural and social sciences when truth claims are made. ${ }^{9}$ The participant in moral argumentation must seek to discursively redeem his claim of normative rightness. He must provide reasons for his claim and open it to public scrutiny. Habermas is careful, however, to observe a strict separation between the normative and theoretical spheres, which avoids the 
reduction of ethics to science. He sees such a reduction as characteristic of intuitionsim and value ethics. ${ }^{10}$ He explains this separation into spheres by claiming that theoretical discourse examines truth claims about the world, while normative discourse investigates claims about the rightness of our intersubjectivly constructed social arrangements.

Habermas division follows from Kant's separation of pure and practical reason. The clarification of our moral ideas is a cognitive process. It is nonetheless different in kind from theoretical cognition because of its different subject matter." For Kant, science rationally investigates the realm of nature and requires sensible intuitions while ethics investigates the realm of freedom a priori. The congnativist nature of Kant's moral philosophy is clear from the subordinate role he ascribes to moral sentiments and his use of juridical argumentation.

In the third section of the Groundwork, Kant provided the ultimate ground for the categorical imperative with a transcendental deduction of human freedom. ${ }^{12}$ His deduction purports to demonstrate the conditions of the possibility of morality itself. He claims, "Every being who cannot act except under the idea of freedom is by this alone - from a practical point of view - really free."13 For Kant, if an individual is to act with intention, then that individual must assume that they themselves are the cause of their actions. Not to do so, i.e. to enter into the discussion of morals while maintaining that one's acts are merely determined, is a contradiction between what one asserts and what one's words and actions presuppose. Kant's transcendental deduction of freedom is not intended to be a positive proof of human freedom, but rather it is merely a defense of freedom analogous to Aristotle's defense of the principle of non-contradiction in the Metaphysics. ${ }^{14}$ Freedom, for Kant, is a "fact of reason" insofar as it is the sine qua non of morality itself.

Habermas moves the cognitivist program of justification beyond Kant by formulating a comprehensive justification for principle U. He attempts to avoid the skeptic's trilema, of infinite regress, incomplete deduction, or circular argumentation by grounding his bridging principles in the idea of a performative contradiction. ${ }^{15}$ A semantic contradiction occurs when both some 
element and its negation are present in the same proposition. A performative contradiction, however, occurs when what is expressed at the semantic level is in conflict with something that is presupposed at the pragmatic level. The statement "I do not exist" is a performative contradiction since the very utterance itself presupposes the negation of the proposition. Habermas argues that the historical critique of universal moral principles like his own, an objection he calls the falliballistic objection, necessarily involves the objector in a performative contradiction. The objector "has to make assumptions that are inevitable in any argumentation game aiming at critical examination." 16 In order to offer a refutation of the cognitivist's claim that he has formulated a universal moral principle, the objector must himself employ universal principles of communication. This, Habermas asserts, is the foundation of the cognitivist program of justification. Principle $U$ is established indirectly through the exposure of performative contradictions in attempted skeptical refutations of $U$.

The fact that the cognitive process of justification of contested norms in both Kant and Habermas is carried out according to a pre-established procedure makes their views formalist. For Kant, when the individual is confronted with a situation that requires action he must "begin with principles (the categorical imperative), proceed to concepts (moral maxims), and only then, where possible, from them to the senses (specific action)."17 The construction of moral judgments follows a clearly defined series of steps. Kant contended that this method of moral reasoning could be taught through the use of casuistical questions. ${ }^{18}$

Habermas' discourse ethics also establishes a procedure for moral argumentation. Habermas articulates this procedure through an additional principle, which he refers to as principle D. Principle D states "Only those norms can claim to be valid that meet (or could meet) with the approval of all affected in their capacity as participants in a rational discourse." 19 Whereas principle U only laid out the criteria for the acceptance of a contested norm, principle $\mathrm{D}$ articulates the method of uncovering whether or not the norm meets the criteria set out in U. Although Kant's is a relatively simple procedure articulated primarily for use within the framework of the daily moral decisions of individuals, ${ }^{20}$ Habermas 
offers a sophisticated account of the procedural dimensions of moral argumentation which are derived from speech act theory.

Habermas distinguishes three levels of presuppositions, viz. logical, dialectical, and rhetorical, which together form the procedural dimension of discourse ethics. ${ }^{21} \mathrm{He}$ claims that these rules of argumentation are not constitutive of discourse but that their denial in actual discourse results in a performative contradiction. The formalism of discourse ethics is essentially captured in an exhaustive list of ways in which a participant in a moral argument can become involved in a performative contradiction.

The deontological, cognitivist, and formalist aspects that characterize both Kant's moral thinking and Habermas' discourse ethics can be summed up with the term universalist. Universalist ethical theories claim to have grounded morality in a manner that is independent of both cultural and historical considerations. Kant suggested that his practical philosophy arose from the examination of human nature and that the categorical imperative is simply a "fact of reason." Habermas argues similarly that discourse ethics arises from the human capacity for linguistic communication and that principle $U$ is a fact of communicative action. Both of these universalist principles purport to transcend any specific historical conditions or particular view of the good and to implicitly establish themselves as the universal moral theory.

II.

I will now take up three specific points of difference between discourse ethics and Kant's practical philosophy that Habermas identifies. Habermas asserts that discourse ethics is superior to Kantianism because it doesn't require Kant's metaphysical postulate of the noumenal realm, because it offers social theory of morality rather than a monological one, and because it justifies the ultimate moral norm in a non-circular way. Habermas believes that these crucial differences allow him rectify the problems of the Kantian position and to establish the universalist position on wholly new ground.

First, there can be no doubt that Habermas gives up the Kantian metaphysical dualism between the empirical world of determinate 
natural laws and the noumenal realm of laws of freedom. What Habermas aims at, following Horkheimer's suggestion, is a "materialist theory of society."22 He claims, "The unbridgable gap Kant saw between the intelligible and the empirical becomes, in discourse ethics, a mere tension manifesting itself in everyday communication as the factual force of counterfactual presuppositions." ${ }^{23}$ What Habermas is claiming here is that the dichotomy of duty and deed which makes Kant's moral philosophy one where only intention matters and the moral worth of an action is only determinable by some postulated deity is overcome in discourse ethics. This dichotomy is overcome insofar as speech acts are themselves actions, but actions that are nonetheless regulated directly by the universal principles of moral argumentation. In any attempt to redeem a normative validity claim, a speaker attempts to come to an understanding with a hearer about some state of affairs in the world. ${ }^{24}$ In doing so the speaker leaves himself open to critique. Habermas argues that the hearer can directly evaluate whether or not the speaker has involved himself in a performative contradiction because both are members of a language community.

Although Habermas' attempt to distinguish himself from Kant succeeds insofar as his theory is situated post-metaphysically, he begs the important question of moral judgement no less than Kant. Despite the fact that the procedural dimension of discourse ethics can be established, at least in an approximate way, prior to any actual discourse, this in no way guarantees that the actual discourse will conform to those procedures. Even if all participants in a moral discourse accept the general rules of moral argumentation, if a situation arises in which it is unclear to different participants whether or not some speaker is involved in a performative contradiction, there is no further principle by which to adjudicate that disagreement.

Habermas would counter the objection that hearers are unable to evaluate speaker's normative validity claims directly with his conception of intersubjectively established communicative competence. ${ }^{25}$ In The Theory of Communicative Action Habermas theorizes, appropriating the view of socialization proposed by $\mathrm{Mead}^{26}$ and Wittgenstein's private language argument, ${ }^{27}$ that because of an individual's socialization into a linguistic community 
any speaker or hearer already knows the rules of discourse and how they are to be applied. The rules of discourse are simply a byproduct of the evolution of symbolically mediated interaction to the level of grammatical language. Because the rules are situated in this evolutionary account they are universal for all language users. Comunicatively competent speakers and hearers just know how the rules of moral argumentation apply because they can communicate. The formal procedures of moral argumentation described in Discourse Ethics are only the inescapable presuppositions of any linguistic communication.

Habermas' conception of communicative competence, however, begs the same question it was intended to answer in two ways depending on how it is argued for. First, if it is asserted that the universal rules of moral argumentation are in the process of being fully elaborated by moral philosophers, as Habermas occasionally does when he refers to "our reconstruction" of the rules, then the falliblistic objection reasserts itself with a newfound vigor. ${ }^{2 \times}$ Participants in discourse must, at every turn, ask, "will the 'real' universal rules of moral argumentation please stand up?" Second, if communicative competence is taken to be the inevitable result of socialization, which arises from an inherently social "human nature," then problems of the opposite sort arise. MacIntyre has identified this argument strategy in several of the chief figures of the enlightenment. "These writers (Kant, Hume, Diderot) share in the project of constructing valid arguments which will move from premises concerning human nature as they understand it to be to conclusions about the authority of moral rules and precepts." 29 Habermas makes the Kantian move of appealing to a "fact of reason" when he invokes the idea of communicative competence in this second way. He argues from human nature to moral precepts, from the universal capacity to use language to rules governing all moral discourse.

The second major difference between discourse ethics and Kant's moral world-view that Habermas observes is that Kant's transcendental consciousness merely assumes that it knows the general interest in making its moral decisions, while the moral agent in discourse ethics leaves this as an open question. ${ }^{31}$ Habermas is both right and wrong to distinguish his theory from Kant's. It is 
true that the formulations of principles $U$ and $D$ move beyond the categorical imperative insofar as they incorporate the principle of the intersubjectivity of norms in to their very formulation. However, it is also the case that Habermas' own ideas can be best understood as the logical development of post-metaphysical Kantianism that is different from Kant not in kind, but only in degree. In order to make the distinction between himself and Kant, Habermas must, on one the one hand overlook the degree to which Kant's moral philosophy is also a political philosophy and on the other, he must conceal the inherent parochialism in his own view.

Both discourse ethics and Kant's moral philosophy are thoroughly political. Moral judgments are not simply matters of individual conscience in particular circumstances for Habermas. They are social matters to be negotiated in the public sphere. The aim of principle $U$ is precisely to work through the conflicts between competing interests in order to establish collectively valid norms. Although Kant distinguishes between private and public morality, there is also a clear continuity between his moral and political ideals. ${ }^{31}$ The categorical imperative, though not formulated in a fashion that explicitly calls for a pluralist testing of maxims, was nonetheless intended by Kant to serve in that capacity. In his essay Perpetual Peace, Kant offers a vision of the sort political arrangements that would be necessary for the public implementation of the categorical imperative as a principle of government. He points out that the C.I. must be the primary consideration for any just sovereign or ruling body. ${ }^{32}$ This sort of politics would not, prima facie, require knowledge of human interests insofar as those interests are already writ large in human nature.

Habermas objects to what he considers to be a monological application of the universal moral principle. The C.I. tells the moral agent, be that agent a single person or a governing body only to treat other people with the dignity that they deserve as rational human beings but it does not provide that agent with any means of discovering what the interests of those affected by the adoption of some maxim actually are. It simply assumes it knows those interests (or establishes them a priori which amounts to the same thing). Consequently, what it actually means to treat particular individuals with respect and dignity remains unclear. According to 
Habermas, the principle advantage of discourse ethics is that it provides a means of discursive will formation in which the articulation of individual interests is possible. The communicatively competent participant in moral discourse can make his or her interests known in and through the process of argumentation. This ostensible advance beyond Kant is not, however, what it seems.

Habermas' revision falls short in two ways. First, as Axel Honneth points out, if an individual or group is not comunicatively competent - i.e. not part of the bourgeois public sphere in one of the western liberal democracies - then their interests are not likely to be expressed in the process of discursive will formation. The type of moral discourse Habermas has in mind presupposes a social milieu permeated by enlightenment rationality. This tacit presupposition would presumably exclude many traditional cultural groups as well as the vast majority of the working class, since these groups generally lack the capacity and means to express their interests through discourse. Consequently, the realization of principle $U$ will not be complete. ${ }^{33}$

A second and even more obvious problem is the question of actually following out the implications of principle $U$. On the face of it, the assertion that all affected parties must be able to consent to the observance of a norm seems logistically impossible or at least highly improbable. If there are to be any norms at all, their establishment will be the result of some elision of principle $U$. Habermas accounts for this necessary inexactitude with principle $\mathrm{D}$ when he claims that valid norms meet or could meet the criteria established in U. However, this proviso is nothing more than the disguised presupposition of the interests of parties who are not able to directly express their interests themselves. The problem is that in either of these cases, despite that fact that a norm is constructed according to the principles of moral argumentation, a norm can be validated without the specific knowledge of interests of the affected parties that Habermas claims is required for the adoption of a norm and is the specific advantage of discourse ethics over Kant. The problem is not one of distorted communication or ideology but of the communicative hegemony of the bourgeois public sphere.

The final point on which Habermas distinguishes his theory from Kant's has to do with the issue of justification. Habermas 
contends that discourse ethics rectifies what he considers to be Kant's unsatisfactory appeal to the "fact of reason" by grounding the universal moral principle in the presuppositions of argumentation. For Habermas, when the "rules" of moral discourse are violated a "performative contradiction" results.

But the opponent will have involved himself in a
performative contradiction if the proponent can show
that in making his argument, he has to make assump-
tions that are inevitable in any argumentation game
aiming at critical examination and that the propositional
content of those assumptions contradicts the principle
of fallibilism.

Habermas claims that this inoculates discourse ethics against the ethical skeptic's attempt to demonstrate infinite regress, incomplete deduction, or circular argument in the establishment of principle $U$. In attempting to develop a refutation of $U$, the skeptic will be obliged to tacitly employ the very principles of argumentation she seeks to deny. Once again, Habermas' claim to have gone beyond Kant is only a matter of degree.

Kant, like Habermas, explicitly grounds his ultimate moral norm in the principle of non-contradiction. ${ }^{35}$ For Kant, "the fact of reason" - viz. the reality of human freedom - is a principle that cannot be positively proven but which also cannot be denied without the individual who denies it involving themselves in a contradiction. ${ }^{36}$ Kant asserts that it is contradictory to deny one's own moral vocation, that is, to deny ones own freedom and the moral consequences that follow from it. Although Kant didn't refer to it as such, this contradiction is exactly what Habermas has in mind when he refers to a performative contradiction. ${ }^{37}$ For Kant the proposition "I am not free" is contradictory because the statement contradicts what is presupposed by its very utterance. The speech-act or thought itself requires the agency of a speaker or thinker. When Habermas claims to have gone beyond Kant in his justification of the ultimate moral norm, he does so by not giving Kant full credit for his achievement. He contends that Kant merely asserts the categorical imperative when in fact Kant secures it 
against the ethical skeptic in the same manner that he secures principle U.

Habermas might counter this claim with the assertion that Kant's employment of the concept of a performative contradiction already assumes a substantive moral content, human freedom and autonomy, while discourse ethics finds its starting point in a "transcendental pragmatics of language" that avoids the inherent difficulties of Kant's assumption of freedom. ${ }^{38}$ Habermas points out that Kant can rightly be accused of petitio principi, yet he doesn't see that discourse ethics is no less susceptible to this charge. ${ }^{39}$ The articulation of a "transcendental pragmatics of language" and a commensurate "minimal logic" of moral argumentation presupposes argumentation as the most "exacting form of discourse" from the very beginning. ${ }^{40}$ This necessarily excludes other possible forms of communication that might possibly have normative import. In addition, as Habermas acknowledges, the question of exactly what constitutes such a "minimal logic" of argumentation remains an open question."

It has been my contention here that, rather than developing any really new moral perspective, Habermas' discourse ethics merely rethinks the basic tenets of Kant's ethical view and overlays them with speech-act theory. Habermas' appeal to "communicative competence" as a ground of morality begs the question no less than Kant's appeal to a "practical reason." Discourse ethics, by changing the assumptions, intends to be less parochial in its application and more open in its consideration of specific interests than the categorical imperative, but these new assumptions are equally monological and exclusionary. Finally, Habermas' appeal to the principle of non-contradiction, as justification in the face of objections is directly inherited form Kant. Habermas' arguing from language use to rules for normative discourse begs the question no less than Kant's argument from the reality of human freedom to the categorical imperative. This is not to say that Habermas' articulation of the basic universalist position is not an advance over Kant's in terms of its theoretical formulation, its social scientific detail, and its abandonment of metaphysics. Despite these modifications however, the basic elements of the po- 
sition, those feature's that elicited Hegel's strongest objections to Kant, remain the same.

\section{III.}

Thus far, I have attempted to explain the general ways in which the ethical theories of Kant and Habermas are alike; each is deontological, cognitivist, formalist, and universalist. I have also argued that Habermas is really not as different from Kant as he claims, particularly in regard to the manner in which he justifies his ultimate moral norm (viz. the appeal to contradiction). At this point, I wish to address the specific responses that Habermas makes to a Hegelian style critique of discourse ethics in his essay Morality and Ethical Life. Habermas recognizes Kant's separation of the problems of justification and application in regard to moral principles as his singular achievement; however, this is exactly the point at which Hegel took Kant to task.

Habermas first takes up Hegel's charge that the formalism of Kant's ethics is empty and that its pronouncements are no more than moral tautologies. Hegel contends, in the first few sentences of his critique of "Morality" in the Phenomenology, that one of the primary difficulties in Kant's view is that it denies Otherness (a similar critique is also undertaken by Hegel in the Philosophy of Right). ${ }^{42}$ The consciousness that knows duty as its absolute essence "cannot receive the form of something alien" and is "completely locked up within itself; it behaves with perfect freedom and indifference towards this Otherness." +3 The leading idea of Hegel's critique is that the "moral consciousness" articulated in Kant's practical philosophy must secure its freedom independently of the natural realm, which renders that freedom completely indeterminate and merely abstract. Duty is consistent with itself only by severing its ties to the world. Habermas concludes that Hegel was wrong to critique Kant in this way insofar as he implies that universal moral principles "postulate logical and semantic consistency and nothing else." $"$ However, Habermas acknowledges that Hegel was right to realize the inherent difficulties in the employment of non-contextual moral principles. 
Habermas replies to the Hegelian critique on this point by asserting, "the content that is tested by a moral principle is generated not by the philosopher, but by real life."45 The problems that the universal moral principle must address are simply "given" as the starting point of any moral discourse. Conflicts between different normative validity claims simply arise in the course of human interaction. For Habermas, these disputes can then be adjudicated in a public moral discourse according to the established rules for moral argumentation.

This manner of meeting Hegel's objection, with its recourse to the given-ness of normative conflicts, fails because, on the one hand, it simply side-steps the central problem Habermas identifies, and on the other, it is inconsistent with regard to the pre-established limits of the universal moral principle as a metaethical principle employed to adjudicate between disputed norms. The categorical imperative is about testing maxims while principles $\mathrm{U}$ and $\mathrm{D}$ are about redeeming normative validity claims. Both the C.I. and principle $U$ are meta-normative; they are not intended to proscribe or sanction particular actions. Principle $U$ may uphold the validity of some particular norm, but it can't fully articulate just how such a norm should be implemented in a specific case. The question "Does the rule apply to 'this' case?" is a matter that cannot be decided by the rule itself. Moral judgment must come into play and some specific action must be taken. The consistency in this relationship is always between the meta-principle and the norm in question (an abstraction from contents) and not between the norm and the action it purports to govern. Hegel was right to point this out.

Habermas realizes that the basis of Hegel's objection was the insight that, up to now in human history, there has been never been, in the words of Alasdair MacIntyre, "morality as such." tion at issue for Hegel was whether or not moral rules could be constructed apart from some concretely articulated vision of the good. Hegel answered this question by asserting that moral principles have always been and must necessarily be inextricably bound up in cultural frameworks that give them force and meaning. This is the essence of Hegel's idea of "ethical life" (Sittlichkeit). Ethical decision-making always depends on context. It depends on 
inherited traditions and concrete historical realities. Universal moral principles must sacrifice their universality or remain content free in the Hegelian view.

Habermas acknowledges these problems when he writes, "Noncontextual definitions of a moral principle, I admit, have not been satisfactory up to now." 47 History provides no examples of any moral viewpoint disengaged from a particular form of life. The general division between principles and actions is a problem for both Kant and Habermas, and it is one both thinkers recognize but nonetheless do not and cannot address. Hegel sumarizes his point of view somewhat sharply when he writes, in reference to Kant,

The moral world-view is, therefore, in fact nothing other than the elaboration of this fundamental contradiction in its various aspects. It is, to employ here a Kantian expression where it is most appropriate, a 'whole nest of thoughtless contradictions. ${ }^{4 / 8}$

Hegel's point is that the process that establishes an ultimate norm and the questions regarding its instantiation in particular circumstances are inextricably linked. The process of justification, whether it is carried out through recourse to the principle of noncontradiction or by other means, cannot be disassociated from the question of application as both Kant and Habermas attempt. For Hegel, the questions of justification and application are inseparable. Moral consciousness, because it fails to recognize the immanent relation between these two aspects of ethical life, must always remain duplicitous in its formulations.

The second criticism of Kant that Habermas brings to the table and attempts to address is what he calls the "abstract universalism of morally justified judgment." 49 Seyla Benhabib, another theorist with neo-Habermasian views, refers to this objection as the "institutional deficiency of Kantian moral theory." "50 Hegel accuses Kant of dissemblance when he asserts,

The moral self-consciousness is its own absolute, and duty is absolutely only what it knows as duty. ...(Moral self-consciousness) iṣ not really in earnest about let- 
ting something be made sacred by another consciousness than itself; for that alone it holds to be sacred which it has itself made sacred, and is sacred in it. ${ }^{51}$

Hegel points to the fact that what universalist moralities offer is not genuine pluralism, but an empty egalitarianism artificially constructed through a faceless equality. The selves bound by the moral law are, so to speak, ethical placeholders and not actual persons. The universalist principle must set itself up as the principle, and, insofar as it does, it is necessarily exclusionary. Again, Habermas both agrees and disagrees with the Hegelian diagnosis.

Habermas disagrees with Hegel insofar as Hegel's criticism suggests that particular interests are necessarily impinged upon by universal moral principles. He argues that modern societies do require regulation and that such regulations will necessarily introduce limitations. As long as compromise achieved through morally justified procedures is sought, then discursive consensus is unnecessary. On this much, it seems, Habermas and Hegel agree. Habermas admits, however, that moral judgments applied monologically, in the manner that Kant's theory conceives them, necessarily lead to situations that are exclusionary but he contends that discourse ethics inoculates itself against this possibility by building in a sensitivity to individuals interests. As I pointed out earlier, the universal expression of interests which Habermas claims saves him from Kant's monologism is only possible for voices that speak the language; those of the of western, liberal, bourgeois. Habermas' principles are no less hegemonic than Kant's. They too exclude their own Other from the discourse.

Habermas notes that Hegel's critique points out the inherent limits of any theory of morality that follows the Kantian model. Such theories, in order to make general claims, must omit many of the details. "They focus on questions of justification, leaving question of application unanswered." 52 Habermas concedes that Hegel is correct about the limits of universalistic moralities but that it is wrong to adopt the neo-Aristotilian solution, which advocates a contextually conditioned faculty of judgment, to this difficulty. Habermas claims "Kant's achievement was precisely to dissociate the problem of justification from the application and implementa- 
tion of moral insights." On the other hand, Hegel's whole point is that this dissociation is harmful rather than helpful (Hegel actually advocates a Hegelian faculty of judgement which attempts to move dialectically from contexts to a view of the whole). ${ }^{53}$ The division between justification and implementation remains a sticking point for universalist ethical theories and Hegel's contention is that one problem can't be resolved independently of the other.

The third criticism that Habermas discusses is Hegel's idea that the division between the sensuous and the intelligible in Kant undermines the practical impact of his moral philosophy. Habermas refers to this as the "impotence of the "Ought." ${ }^{54}$ He concurs with Hegel's criticism of Kant, but claims that discourse ethics escapes this charge since it secures itself through the presuppositions of argumentation. As I have already shown, however, Habermas' reformation of Kant doesn't really eliminate this division, but dresses it up in new clothes that conceal its inner contradictions. Habermas covers over this problem with his equivocal theory of communicative competence. He concedes that Hegel is correct in asserting that a universalist practical discourse must, necessarily, disconnect practical problems from their contexts, but he adds the proviso that this is only for the greater good that a re-integration of discursively established norms into their life-world contexts offer. Habermas argues that disparate forms of life "must meet universalist moralities half-way" in order to solve the problems brought about by the instrumental rationalization of the life-world. However, this "meeting halfway" most certainly involves a denaturation of those forms of life that can only be questioned after the fact. ${ }^{55}$ The progressive rationalization of the life-world closes off the possibility of a "hermeneutic" perspective, which recognizes the autonomy and legitimacy of other forms of life. Habermas calls for the sacrifice of traditional moralities while offering no guarantee but a utopian faith in the power of discourse to mitigate deeply entrenched practical problems. Hegel's own view of ethical life embodies a similar hope for the mediating power of dialogue without, however, putting participating traditions at stake.

The last dimension of the Hegelian critique of Kant that Habermas addresses is the notion that universalist moralities lead to totalitarian political regimes. Habermas argues that such results 
are not in accord with the spirit or letter of either Kantianism or discourse ethics, however, it is nonetheless the case that universalist moralities presuppose a totalizing ideology - the ideology of universal rationality. This type of objection is not one that Hegel levels explicitly against Kant, but one that can be inferred from his critique. The idea of liberal democracy, inherited from Locke and completed the in greatest minds of the enlightenment became the ideal that the French revolution was an attempt to realize by force. Discourse ethics too has as its final goal the realization of the freedom of every individual through a homogenization of interests. Habermas explicitly endorses this goal:

\begin{abstract}
Universalist moralities are dependent on forms of life that are rationalized in that they make possible the prudent application of universal moral insights and support motivations for translating insights into moral action. Only those forms of life that meet universalist moralities halfway in this sense fulfill the conditions necessary to reverse the abstractive achievements of decontextualization and demotivation. ${ }^{56}$
\end{abstract}

Discourse ethics is unable to meet non-rationalized life-worlds on their own terms. To the extent that discourse ethics requires and seeks to perpetuate the rationalization of forms of life which otherwise would be unable to participate and articulate their interests, it is totalitarian. It is unable to afford those forms of life recognition (Anerkennug) in any but its own terms.

In conclusion, I wish to summarize my argument. Since the differences between Kant and Habermas are only superficial, Hegel's criticisms of Kant apply equally to Habermas. By contrasting Habermas' conception of the moral intuitions of discourse ethics with the concrete moral situation that Hegel reveals in the Phenomenology, some of the inherent limitations of discourse ethics, and universalist ethical theories in general, are revealed. To review; first, the separation of justification and application that a universalist ethics requires from the outset, renders it unable to achieve any reconciliation between these elements without recourse to dissemblance (i.e. hiding the separation). Second, the univer- 
salist position excludes all otherness in theory and, consequently, is inevitably exclusionary in practice. Hegel's critique of Kant reveals the immanent contradiction between the two professed aims of discourse ethics; the establishment of an ultimate principle to adjudicate between contested norms and the establishment of truly egalitarian social arrangements. Third, Hegel's critique of Kant's two-view points doctrine is not overcome by Habermas' reliance on communication theory to ground principle U. Habermas' theory of communicative competence is a dual-aspect theory of the same stripe as Kant's. Finally, the incapacity of the Kantian moralist to recognize his other is also present in discourse ethics and is the necessary pre-condition for totalitarianism.

In general, the failures of Kant's moral theory that are repeated in Habermas' discourse ethics are not so much the result of Habermas' misreading of Hegel's specific criticisms of Kant, but of his failure to understand Hegel's view of language. Habermas understands the "linguistic turn" in western philosophy as a postHegelian development rooted in Anglo-American analytic scholarship, the social sciences, and speech-act theory. It was Hegel, however, who, through his critiques of Kant and the Romantics exposed the inherent limitations of the "philosophy of consciousness" paradigm and emphasized the significance of language and its role as the medium of recognition in ethical life.

Habermas claims that he is following Hegel insofar as discourse ethics aims at the same reconciliation that Hegel sought between, on the one hand, individual rights and the principle of justice, and, on the other, the integrity of the community and the principle of solidarity. ${ }^{57}$ Such an ideal relation, Habermas assents, is embodied in Hegel's notion of Sittlichkeit. For both Habermas and Hegel, this ideal is realized in language, but it is realized in very different conceptions of language. Comparison of the following statements, the first by Habermas and the second by Hegel, brings the contrast in their respective views of language into sharp relief. Habermas' view of language stems from the approach necessarily taken by Understanding (following Kant's use of this term).

There is only one reason why discourse ethics, which presumes to derive the substance of universalistic mo- 
rality from the general presuppositions of argumentation, is a promising strategy: discourse or argumentation is a more exacting type of communication, going beyond any particular form of life. Discourse generalizes, abstracts, and stretches the presuppositions of contextbound communicative actions by extending their range to include competent subjects beyond the provincial limits of their own particular form of life. ${ }^{58}$

Hegel, in contrast, speaking from the standpoint of Reason (following Hegel's use of this term), writes,

Here again, then, we see language as the existence of Spirit. Language is self-consciousness existing for others, self-consciousness which, as such is immediately present, and this self-consciousness is universal... It perceives itself just as it is perceived by others, and the perceiving is just existence which has become a self..$^{59}$

Hegel's view holds out for a richer view of language that is not simply reducible to the presuppositions of argumentation, a form of language constitutive of the self and concrete. He explains the Kantian view by way of contrast with his own.

Moral consciousness, on the other hand, is still dumb,
shut up with itself within its inner life, for there the self
does not as yet have an existence: existence and the
self stand as yet only in an external relation to each
other. Language, however, only emerges as the middle
term, mediating between independent and acknowl-
edged self-consciousnesses; and the existent self is
immediately universal acknowledgment...6

For Hegel, the self, the individual moral agent, is not possible in the abstract. Language that only abstracts does not perform its most essential function of publicly constituting the self. The exacting language of discourse that Habermas prescribes as the antidote to the most recalcitrant contemporary moral conflicts fails to include language's expressive function, which Hegel understood 
as essential to the attainment of the ethical goal of mutual recognition. Language that ardently eschews contradiction fails to grasp the dialectical nature of thought and language. It cannot perform its function as the medium of recognition. For Hegel, the self, as a universal, is constituted by the particular details of its context and history. In Hegel's view, it is only with the full cognizance of the details of the individuals involved that moral dialogue, rather than mere moral argument, can be carried out.

\section{Notes}

' Jurgen Habermas, "Morality and Ethical Life: Does Hegel's Critique of Kant Apply to Discourse Ethics," Moral Consciousness and Communicative Action, trans. Christian Lenhardt and Shierry Weber Nicholsen (Cambridge: Mit Press, 1990) 195-212.

2 Habermas conception of discourse ethics draws heavily from the work of K.O. Apel. K.O. Apel, "The A priori of the Communication Community and the Foundations of Ethics," in Towards a Transformation of Philosophy (London, 1980). ; K.O. Apel, "The problem of Philosophical Foundations Grounding in Light of a Transcendental Pragmatics of Language," in K. Baynes, J. Bohman, and T. McCarthy, eds. After Philosophy (Caimbridge Mass: Mit Press, 1987).

${ }^{3}$ These criticisms are not found directly in Hegel's texts, but are, rather, Habermas' interpretation of Seyla Benhabib's reformulated Hegelian criticisms. She articulates them in the following way: "(a) the procedural critique of the universalizability principle, (b) the institutional deficiency of Kantian moral theory, (c) the critique of Kant's moral psychology, and (d) the critique of Kant's theory of action." In some sense, Habermas' essay can be read as a response to Benhabib. Seyla Benhabib, Critique, Norm and Utopia: A Study of the Foundations of Critical Theory (New York: Columbia University Press, 1986) 297.

"Habermas, "Morality and Ethical Life," 210.

"Habermas, "Morality and Ethical Life," 196.

"Roger Sullivan, Immanuel Kant's Moral Theory (New York: Cambridge University Press, 1989) 234.

7 Immanuel Kant, The Groundwork of the Metaphysics of Morals, trans. by Mary Gregor with an introduction by Christine Korsgaard (New York: Cambridge University press, 1998) 73.

${ }^{8}$ Habermas, "Discourse Ethics," Moral Consciousness, 65.

${ }^{y}$ Habermas, "Morality and Ethical Life," 196. 
11 Ibid.

"Kant, Groundwork, 43.

12 Ibid.,52-66.

13 Ibid., 53.

14 Sullivan, Kant's Moral Theory, 84.

15 Habermas, “Discourse Ethics," 80.

"Habermas, "Discourse Ethics," 81.

17 Immanuel Kant, The Critique of Practical Reason, trans. Mary Gregor with an introduction by Andrews Reath (New York: Cambridge University Press, 1997) 13.

18 Ibid., 127.

${ }^{19}$ Habermas, “Discourse Ethics,” 66.

${ }^{20}$ This interpretation of Kant's procedural apparatus somewhat misrepresents Kant's intentions for his moral theory insofar as it suggests that testing maxims with the categorical imperative is something that only individuals qua individuals do. In fact, it is clear in the from his essay "Perpetual Peace" I Imanuel Kant, The Cambridge Edition Of the Works of Immanuel Kant, Practical Philosophy ed. Mary Gregor (Cambridge: Cambridge University Press, 1996).\} that Kant envisioned nations a using the same procedure to govern their collective actions and political dealings.

${ }^{21}$ On the logical level every speaker must observe the following rules; a.) No speaker may contradict himself, b.) all speakers must be consistent in their application of predicates, and c.) different speakers may not use the same expression with different meanings. These rules have no specifically moral content. On the dialectical level, every speaker must a.) assert only what he really believes and b.) provide a reason for wanting to do so if he wishes to dispute a norm not under consideration. Finally, on the rhetorical level, it is asserted that; a.) every subject with communicative competence is allowed to take part in the discourse, b.) that any participant can question any assertion, and c.) that no speaker can be prevented for exercising his rights through coercion.

${ }^{22}$ Habermas, "Morality and Ethical Life," 211.

23 Ibid., my Italics.

${ }^{24}$ Jurgen Habermas, "Toward a Critique of the Theory of Meaning," Post-Metaphysical Thinking...Philosophical Essays, trans. by W.M. Hohengarten (Caimbridge: MIT Press, 1993) 58.

25 Jurgen Habermas, The Theory of Communicative Action vol II, trans. by Thomas McCarthy (Boston: Beacon Press, 1987) 7-27.

${ }^{26}$ G.H. Mead, Mind, Self, and Society, (Chicago: The University of Chicago Press, 1934). 
${ }^{27}$ Ludwig Wittgenstein, Philosophical Investigations, trans. G.E. M Anscombe (New York: Macmillan Company, 1958) par. 201.

${ }^{28}$ Habermas, "Discourse Ethics," 97.

${ }^{29}$ Alasdair MacIntyre, After Virtue (Notre Dame: University of Notre Dame Press, 1981) 52.

${ }^{30}$ Habermas, "Morality and Ethical Life," 203.

${ }^{31}$ Immanuel Kant, The Metaphysics of Morals, trans. Mary Gregor with an introduction by Roger Sullivan (New York: Cambridge University Press, 1996) 33.

${ }^{32}$ Kant, "Perpetual Peace," The Cambridge Edition Of the Works of Immanuel Kant, Practical Philosophy ed. Mary Gregor (New York: Cambridge University Press, 1996) 348.

${ }^{33}$ Axel Honneth, The Struggle for Recognition, trans. with an introduction by Joel Anderson (Cambridge: MIT University Press, 1995) 176-179.

${ }^{34}$ Habermas, "Discourse Ethics," 81.

${ }^{35}$ Kant also employs the principle of non-contradiction in a secondary sense as part of the testing of maxims against the C.I., however, a discussion of this use of the principle of non-contradiction by Kant is lies outside the scope of my argument.

${ }^{36} \mathrm{Kant}$, Groundwork, 43n.

${ }^{37}$ Habermas, "Discourse Ethics," 80.

${ }^{38}$ Ibid., 78.

${ }^{39}$ Ibid.

${ }^{40}$ Habermas, "Morality and Ethical Life," 202.

"Habermas, "Discourse Ethics," 81.

42 G.W.F. Hegel, The Phenomenology of Spirit, trans. A.V. Miller with introduction and notes by J.N. Findlay (New York: Oxford University Press, 1977) par. 599. and The Philosophy of Right, ed. Allan W. Wood and trans. H.B Nisbet (United Kingdom: Cainbridge University Press, 199) 157-167. Hegel writes on page 163, "if we demand of a principle that it should also be able to serve as a principle of universal legislation, this presupposes that it already has a content; and if this content were present, it would be easy to apply the principle. But in this case the principle itself is not yet available, and the criterion that there should be no contradiction is non-productive - for where there is nothing, there can be no contradiction either."

${ }^{43}$ G.W.F. Hegel, The Phenomenology of Spirit, trans. A.V. Miller with an introduction and notes by J.N. Findlay (New York: Oxford University Press, 1977) par., 599.

"Habermas, "Morality and Ethical Life," 203.

45Ibid., 204. 
${ }^{46}$ Alasdair MacIntyre, After Virtue, 265.

${ }^{47}$ Habermas, "Morality and Ethical Life," 205.

${ }^{48}$ Hegel, The Phenomenology of Spirit, par., 617.

49 Habermas, "Morality and Ethical Life," 205

${ }^{50}$ Seyla Benhabib, Critique, Norm and Utopia: A Study of the Foundations of Critical Theory, 297.

${ }^{51}$ Hegel, Phenomenology, par. 626.

${ }^{52}$ Habermas, "Morality and Ethical Life," 206.

${ }^{53}$ Ibid.

${ }^{54}$ Ibid., 207.

${ }^{55}$ Habermas, "Discourse Ethics," 109.

${ }^{56}$ Ibid.

${ }^{57}$ Habermas, "Morality and Ethical Life," 200.

${ }^{58}$ Ibid., 202.

${ }^{59}$ Hegel, Phenomenology, par. 652

${ }^{60}$ Ibid., par. 653. 